Published with Open Access at Journal BiNET

Vol. 04, Issue 01: 198-205

International

\title{
Strategic planning and goal attainment of polytechnics in Ondo state of Nigeria
}

\section{Hope Ngozi Nzewi ${ }^{1}$, Mary Onwuka Ebele $^{1}$ and Olawole Samson Alaba ${ }^{2}$}

${ }^{1}$ Faculty of Management, Nnamdi Azikiwe University, Awka

${ }^{2}$ Dept. of Vocational Education, Faculty of Education, Nnamdi Azikiwe University, Awka, Nigeria

\section{$\triangle$ For any information: ask.author@journalbinet.com}

Received: 17 June 2017; Revised: 04 August 2017 and Published online: 25 September 2017.

\begin{abstract}
Polytechnics are bedevilled with myriads of problems that can jeopardize the attainment of their goal. Some of these problems are related to finance and equipment. The objective of the study is to examine the relationship between strategic planning and goal attainment of polytechnics in Ondo State of Nigeria. The study used correlational research design and questionnaire was the instrument used to collect data from the respondents. The mean and standard deviation were used in analyzing the data while Pearson Product Moment Correlation coefficient was used to test the relationship between strategic planning and goal attainment of the polytechnics. The findings of the study revealed among other things that there was a significant positive relationship between strategic planning and goal attainment of the Polytechnics. It is therefore recommended that the polytechnics should sustain and improve on the implementation of their strategic planning so as to continually achieve its goal in the face of challenges.
\end{abstract}

Key Words: Education goal, Planning process, Manpower, Challenges and Formula

Cite Article: Nzewi, H. N., Ebele, M. O. and Alaba, O. S. (2017). Strategic planning and goal attainment of polytechnics in Ondo state of Nigeria. International Journal of Business, Management and Social Research, 04(01), 198-205. Crossref: https://doi.org/10.18801/ijbmsr.040117.23

Article distributed under terms of a Creative Common Attribution 4.0 International License.

\section{Introduction}

Strategic planning appears to be the tool for achieving and sustaining productivity in organization. In the educational sector particularly tertiary institutions like the polytechnics little is known about the use of strategic planning and how it is impacting on their performance. Since no organization be it business or educational is immuned or insulated from challenges, the potency of which can cripple their activities and jeopardize their survival, the use of strategic planning may enable them realize their goal and survive the turbulent challenges of the present and future. Strategic planning can be of help on goal attainment. 
Strategic planning is an action plan that defines where an organization wants to be in some years to come and how to be there. Strategic planning projects into the future and how to arrive at that future for the organization. Goal represents the mission of an organization and the very reason for its existence. The success of strategic planning is hinged on its effective implementation otherwise it may be an exercise in futility. Strategy formulation without strategy implementation is useless (Hrebeniak, 2008; Cater and Pucko, 2010). A good strategic plan without a good implementation can result into a doom for the planning and the organization.

In Nigeria, polytechnics are part of tertiary institutions. The goal of polytechnic education as spelt out by the body in charge of regulating the affairs of polytechnic institutions, (Federal Ministry of Education, 2004) is to produce middle level technical manpower needed for industrial and technological development of the country. The volatile and unstable conditions under which the polytechnics are operating are indicators of the need for the polytechnics to consider the adoption of strategic planning to enable them attain their primary goal and also be relevant in the development of the country and for the institutions to survive and remain relevant. In the face of daunting challenges, polytechnics need to be proactive. Strategic planning is a proactive measure designed to forestall failure and make success possible even in the midst of daunting internal and external challenges. If strategic planning is strategically implemented, it can be arguably and reasonably predicted that organizations would undoubtedly achieve their goal and objectives. The failure of most of the strategic plans stems from the poor quality of the plan and poor implementation (Resnick, 2010; Khadem, 2008; Koseoglu et al., 2009). An ideal strategic planning and implementation should be able to survive moderate challenges and at the end of them all, deliver on its goal.

The polytechnic educational goal is attained when the institution is able to produce middle level technical manpower needed for industrial and technological development of the country. The attainment of the educational goal also requires the graduates of the polytechnic to have the capacity and capability from the knowledge and skills acquired to function effectively in the world of work. Lack of a strategic plan and failure to implement strategic plan where it exists may be what is responsible for most of the challenges confronting the polytechnics and other tertiary institutions. It is for this reason therefore that this paper seeks to determine the relationship between strategic planning and goal attainment of Polytechnics in Ondo State of Nigeria.

\section{Statement of the problem}

Business organizations have adopted strategic planning as a tool for achieving and sustaining organizational performance and success. The effects of strategic planning on performance in the business sector are usually measured and predicated on organisation's profitability, market share, earnings per share, net asset, working capital and expansion. (Owolabi and Makinde, 2012). However, these performance indices of strategic planning effectiveness in business organizations cannot be used in the educational sector (tertiary education). Since the goals of tertiary institutions differ from that of a business organization, nonetheless, strategic planning can still be used in the tertiary institutions particularly polytechnics, to achieve their goal.

Many challenges are facing the educational sector of which the polytechnic is not an exception. The challenges according to Owolabi and Makinde (2012) include among other things: distorted academic calendar, industrial disputes, inadequate water supply, decayed facilities - hostel accommodation, laboratories, classroom facilities, challenges of accreditation and re-accreditation, deteriorating quality of graduates. Other challenges facing tertiary institutions are poor funding, lack of office furniture items for staff and lack of resources for teaching. These problems may jeopardize the realization of polytechnic educational goal of producing middle level technical manpower needed for industrial and technological development of the country. Already, there are insinuations from some quarters on the ability of the polytechnics to achieve their goal arising from reports on the poor performance of the polytechnic graduates in the world of work.

One begins to wonder whether strategic planning is not used in the polytechnic or is not strategically implemented. The myriads of problems confronting the institutions are becoming more gargantuan, hence this study was undetaken. 
The major objective of the study was to determine the relationship between strategic planning and goal attainment of polytechnics in Ondo State of Nigeria. The specific objective of the study is to assess the extent of the relationship between strategic planning and goal attainment of the polytechnics.

\section{Research questions}

The following research questions were generated for the study:

$>$ What is the relationship between strategic planning and goal attainment of the polytechnics in Ondo State of Nigeria?

$>$ What is the extent of the relationship between strategic planning and goal attainment of the polytechnics?

\section{Hypothesis}

The following null hypothesis was formulated for the study:

There is no significant relationship between strategic planning and goal attainment of polytechnics in Ondo State of Nigeria.

\section{Review of literature}

\section{Conceptual and theoretical framework}

\section{Conceptual framework}

Strategy is a broad based formular on how organization is going to compete and what policies will be needed to carry out the goals in order to achieve success (Aremu, 2010 and Kazmi, 2008). Strategic planning is a process of developing a vision of the future and developing the necessary procedures and operations to influence and achieve that future. Without a vision of the future, an organization is doomed in the future. strategic planning is a tool for finding the best future for your organization and the best path to reach that destination (Akinyele and Fasogbon, 2007).

According to Parker (2010) cited in Gideon et al. (2004), the planning process consists of the following:

$>$ Preparation phase;

$>$ Overview of the strategic planning process;

$>\quad$ The strategic intent;

$>\quad$ Taking 360 degree stock;

$>$ Formulation of the strategy;

$>$ Refining and consolidating the strategic plan;

$>$ Implementing the strategic plan; and

$>\quad$ Evaluating the strategic plan.

\section{Strategic planning process}

A strategic process is a step-by-step, ongoing and results-oriented roadmap that enables the organization to achieve its mission and vision (Grensing-Pophal, 2011). The roadmap is rolled out for the next two to three years (Shapiro, 2010; Grensing-Pophal, 2011). The strategic planning process therefore involves the strategic planning, implementation, monitoring and evaluation (Schilder, 2010).

\section{Preparation phase}

The route to quality strategic planning or world-class practices begins with the facilitator's preparation, participant preparation and the preparation of the organization (Parker, 2010). Unless things are done right the first time, it cannot be expected that they would be fixed at a later stage (Frigon and Jackson, 2009). 


\section{An overview of the strategic planning process}

An overview of the strategic planning process involves "looking at the past, the present and the future". The process "entails an assessment of the organization, its resources, and its environment and encompasses the setting of objectives" (Carroll, 2010). An overview of the strategic planning process also focuses on the roles of the sponsor, the facilitator and the participants as well as on the rules of engagement (Parker, 2010).

\section{Strategic intent}

"Strategic intent is about creating a sense of urgency through the setting up of an overarching ambitious goal that stretches the organization and focuses on winning in the long run, which gives a sense of direction and purpose to members of the organization" (Ehlers and Lazenby, 2007). The strategic intent can be the basis of the business purpose or mission, vision, brand promise and organizational values (Parker, 2010).

\section{Taking 360 degree stock}

The 360 degree assessment involves the assessment of the external environment as well as the internal environment of the organization. Once this is done, it gives way for the formulation of the organisation's strategy. (Gideon et al., 2014). An all round assessment of opportunities, strengths and weaknesses as well as challenges both within and without must be carried out so that an appropriate goal and strategy can be formulated.

\section{Formulation of strategy}

The fifth phase of the strategic planning process is the formulation of the organization's strategy (Parker, 2010). Strategies are broad based formulae and measures on how business is going to implement its strategic plan and achieve its objectives.

\section{Refinement and consolidation of the strategic plan}

The formulation of the strategy is followed by the refinement and consolidation of the strategic plan. This process involves the taking of the organisation's newly formulated strategy to the 'corridors and cubicles' of the organization (Niven, 2006). When the strategy is taken through the various units of the organization through the process of cascading, there is organizational integration that makes the organisation's various units to be interdependent of each other.

\section{Implementation of the strategic plan: Performance Management System}

When the strategic plan and the business plan have been cascaded down to the operational level for delivery by the organisation's workforce and where their execution is critical, they are seamlessly flown and aligned into the Performance Management System. Therefore performance management System should begin with a clear understanding of the organisation's strategic planning process (Parker, 2010).

\section{Strategy implementation components}

Once a sound strategic plan is in place and it has been cascaded from the corporate level to the operational and individual level, the strategic plan implementation begins. Strategy implementation should not be regarded as distinct from strategy formulation. Strategy formulation and strategy implementation are interdependent and are only two sides of the same coin (Hrebiniak, 2006).

\section{Evaluation of the strategic plan}

The evaluation of the strategic plan is the final phase of the strategic planning process. The monitoring and evaluation phase focuses on how good, useful or successful the strategic plan is, and what else needs to be done and why. The focus is on the internal workings of the organization and what is working well is left unchanged whereas what is not working well is tackled and corrected in order to achieve the desired results. 


\section{Theoretical framework}

The theory upon which this study is based is the Systems theory. According to Nnabuife (2009), a system is a whole made up of interrelated parts called subsystems that worked together to achieve a goal(s). The system theory differs from the other theories of management which viewed different aspects of the organization. According to Nnabuife (2009), the system theory took a holistic view of the organization as being made of different parts. Some concepts that are usually associated with the systems theory are: sub-systems, synergy, systems boundary and feedback. The implication of the systems theory is that since the polytechnic is made up of different structures and substructures, and the institution is subjected to both internal and external factors, there must be strategic planning that defines and integrates every activity towards goal attainment. There must be an holistic response to internal and external factors that are counter productive to the attainment of organizational goal.

\section{Materials and Methods}

This study made use of correlational survey research design and carried out in the year 2016. This method is appropriate due to the quantitative and descriptive nature of the study (Ogunyankin, 1999; Aborisade, 1997). The population of the study was made up of all the senior administrative staff and academic staff of Rufus Giwa Polytechnic, Owo and Federal Polytechnic, Ile-Oluji in Ondo State. The sample of study consisted of 70 people taken from the population through a simple random sampling technique. The composition of the sample was 40 academic staff and 30 administrative staff. A structured questionnaire was used to collect data from the respondents.

Questionnaire was used because of its flexibility to gather information concerning almost any topic, from a large or small population (Olatokun and Gbinedion, 2009). A four-point rating scale of strongly agree -4 points, Agree -3 points, Disagree -2 points and strongly disagree -1 point, was used to grade the items on the questionnaire. The researcher personally administered copies of the questionnaire on the respondents while the collection of the completed questionnaires was also done by him. The statistical tools used for the analysis of the collected data were mean and standard deviation while the Spearman's Moment Correlation Coefficient was adopted to test the relationship between the two variables. The study was.

\section{Results and Discussion}

Table 01. Response to the relationship between strategic planning and goal attainment of polytechnics in Ondo State of Nigeria

\begin{tabular}{lllll}
\hline Items & NO & X & SD & Remarks \\
\hline $\begin{array}{l}\text { There is a positive relationship between strategic } \\
\text { planning and goal attainment of the polytechnics. }\end{array}$ & 3.71 & 0.49 & Agree \\
$\begin{array}{l}\text { Strategic planning directs all activities towards goal } \\
\text { attainment. }\end{array}$ & 70 & 2.93 & 1.03 & Agree \\
$\begin{array}{l}\text { Strategic planning specifies individuals duties towards } \\
\text { goal attainment. }\end{array}$ & 30 & 3.21 & 0.95 & Agree \\
$\begin{array}{l}\text { Strategic planning channels resources towards goal } \\
\text { attainment. }\end{array}$ & 30 & 3.43 & 0.73 & Agree \\
$\begin{array}{l}\text { Strategic planning provide direction towards goal } \\
\text { attainment. }\end{array}$ & 30 & 3.43 & 0.73 & Agree \\
\hline
\end{tabular}

From the statistical data presented in table one above, the mean of each of the five items is higher than the bench-mark mean of 2.5. This indicates that strategic planning has positive relationship with the goal attainment of the polytechnics. 
Table 02. The extent of the relationship between strategic planning and goal attainment of the polytechnics in Ondo State of Nigeria

\begin{tabular}{lllll}
\hline Items & NO & X & SD & Remarks \\
\hline $\begin{array}{l}\text { Strategic planning and goal attainment are inseparable } \\
\text { bed fellows. }\end{array}$ & 70 & 3.21 & 0.88 & Agree \\
$\begin{array}{l}\text { Achieving the mission of polytechnic is a function of } \\
\text { strategic planning. }\end{array}$ & 30 & 3.29 & 0.69 & Agree \\
$\begin{array}{l}\text { Goal attainment is only possible when strategic } \\
\text { planning is in place. }\end{array}$ & 30 & 3.71 & 0.49 & Agree \\
$\begin{array}{l}\text { Lack of strategic planning or deviation from it would } \\
\text { make goal attainment difficult or impossible. }\end{array}$ & 30 & 3.57 & 1.02 & Agree \\
$\begin{array}{l}\text { Goal without a plan to follow for its attainment is } \\
\text { doomed. }\end{array}$ & 30 & 3.86 & 0.32 & Agree \\
\hline
\end{tabular}

From the statistical data presented in table 03 above, the mean obtained to each of the five items is higher than the bench mark mean of 2.5. This implies that the extent of the relationship between strategic planning goal attainment of the polytechnics is very high.

\section{Testing of Hypothesis}

Table 03. Test of relationship between effects of strategic planning and goal attainment of polytechnics in Ondo State of Nigeria

\begin{tabular}{llllll}
\hline Variable & $\mathrm{N}$ & Mean & SD & r & Remarks \\
\hline Strategic planning & 70 & 3.21 & 0.95 & & \\
Goal attainment & 70 & 2.93 & 1.03 & 0.27 & Ho is rejected \\
\hline
\end{tabular}

Since the calculated $\mathrm{r}$ is $0.27, \mathrm{H}_{0}$ is therefore rejected meaning that there is relationship between strategic planning and goal attainment of polytechnics in Ondo State of Nigeria. There is relationship between strategic planning and goal attainment of polytechnics in Ondo State.

\section{Discussion}

From the analyses of the responses to items 1-5 in table one, the respondents agreed with all the statements on the relationship between strategic planning and goal attainment of polytechnics. Each of the mean of the five items was higher than the benchmark mean of 2.5. From the response to item one in table one, it is obvious that positive relationship exists between strategic planning and goal attainment of the institutions. This is evidenced through the positive response to item 3 with a mean of 3.21 and standard deviation of 0.95 . Also, the use of strategic planning makes the realization of the polytechnics goal possible. This can be seen in items 4 and 5 in table one. From the analyses of the responses to items 1-5 in table 02 , all the respondents agreed on the statements relating to the extent of the relationship between strategic planning and goal attainment of the polytechnics. The responses to the items in table 02 show a mean of $3.21,3.29,3.71,3.57$ and 3.86 respectively. This is an indication of a very high relationship.

\section{Conclusion and Recommendations}

The only way in which the polytechnics can justify their existence and huge sums of money being spent on them is to attain their primary goal of producing middle level technical manpower for the industry and technological development of the country. The realization of this noble goal calls for the formulation of strategic planning and the strategic implementation of the plan.

Strategic planning is one of the keys for the attainment of polytechnic goal as there is a relationship between strategic planning and goal attainment.

\section{Major findings:}

There is a positive relationship between strategic planning and goal attainment of polytechnics in Ondo State. 
$>$ The extent of the relationship between strategic planning and goal attainment of the polytechnics in Ondo State is very high.

\section{Recommendations:}

$>$ The polytechnics should embrace the use of strategic planning to enable them realize their goal.

$>$ The polytechnics should carry out strategic implementation of their strategic planning.

$>$ The attainment of polytechnic educational goal should be tied to the formulation of strategic planning and strategic implementation of the plan.

\section{References}

[1]. Aborisade, F. (1997). Research Methodology. A Student Handbook. Multi-Firm Limited Publisher.

[2]. Akinyele, S. T. and Fasogbon, O. I. (2007). Impact of strategic planning on organisational performance and survival. Research Journal of Business Management, 1, 62-71. https://doi.org/10.3923/rjbm.2007.62.71

[3]. Aremu, M. A. (2010). Enhancing organizational performance through strategic management: conceptual and theoretical approach. Retrieved on 20 October 2011 from www.stratplanning/performance.

[4]. Carroll, A. B. (2010). Three types of management planning: Making organizations work. Management Quarterly, 34, 1-2. Retrieved on 10 June 2007 from http://www.questia. com/googleScholar.qst?docld=5002 194623.

[5]. Cater, T. and Pucko, D. (2010). Factors of effective strategy implementation: Empirical evidence from Slovenian business practice. Journal for East European Management Studies, 15(3), 207-236.

[6]. Ehlers, T. and Lazenby, K. (2007). Strategic management: Southern African concepts and cases. (2 ${ }^{\text {nd }}$ edition). Pretoria: Van Schaik.

[7]. Federal Minitry of Education (2004). National Policy on Education, Lagos, Federal Government of Nigeria Press.

[8]. Frigon, N. L. and Jackson, H. K. (2009). Enterprise excellence: A practice guide to word-class competition. Hoboken, New Jersey: John Willey \& Sons, Inc.

[9]. Gideon, N. N., Werner, P. and Wilfred, I. V. (2014). The Role of quality strategic planning an organizational success. Mediterranean Journal of Social Sciences, 5(1), 697-708.

[10]. Grensing-Pophal, L. (2011). The Complete Idiot's Guide to Strategic Planning. ALPHA - A Member of Penguin Group (USA) Inc.

[11]. Hrebiniak, L. G. (2006). Obstacles to effective strategy implementation. Organizational Dynamics, 35(1), 12-13. https://doi.org/10.1016/j.orgdyn.2005.12.001

[12]. Hrebiniak, L. G. (2008). Making strategy work: Overcoming the obstacles to effective execution. Ivey Business Journal, March/April, pp. 1-6.

[13]. Kazmi, A. (2008). Strategic management and business policy (3rd ed.). New Delhi McGraw-Hill Companies.

[14]. Khadem, R. (2008). Alignment and follow-up: Steps to strategy execution. Journal of Business Strategy, 29(6), 29-35. https://doi.org/10.1108/02756660810917219

[15]. Koseoglu, M. A., Barca, M., Karayormuk, K., and Edas, M. (2009). A study on the causes of strategies failing to success. Journal of Global Strategic Management (JGSM), 3(2), 77-90. https://doi.org/10.20460/JGSM.2009318462

[16]. Niven, P. R. (2006). Balanced Scorecard Step-by-step. Hoboken, New Jersey: John Wiley and Sons, Inc.

[17]. Nnabuife, E. K. N. (2009). Organisational behaviour and management theory. Nimo. Rex Charles \& Patrick Ltd.

[18]. Olatokun, W. M. and Gbinedion, L. J. (2009). The adoption of automatic teller machines in Nigeria: An application of the theory of diffusion of innovation. Issues in informing science and information technology, 6, 373-393.

[19]. Ogunyakin, S. O. (1999). Research Methodology and Project Writing. Pawed Publication. 
[20]. Owolabi, S. A. and Makinde, O. G. (2012). The effects of strategic planning on corporate performance in University education: A study of Babcock University. Kuwait Chapter of Arabian Journal of Business and Management Review, 2(4), 27-44.

[21]. Parker, A. J. (2010). Workshop. pp. 1-7.

[22]. Resinick, H. S. (2010). Organisational strategic planning processes. Retrieved from http://www.worksystems.com/services/strategicplanning.html.

[23]. Schilder, D. (1997). Strategic planning process: Steps in developing strategic plans reaching results Harvard family research project: Harvard Graduate School of Education.

Retrived 02 August 2012 from http://www.hfrp.org/publications.-resources/browse-ourpublications/strategic-plans.

[24]. Shapiro, J. (2010). Strategic planning toolkit. Retrived 06 December 2012 from toolkits@civicus.org. 